\title{
コミュニティ活動が水害対応や対策への役割分 担に与える影響に関する研究 \\ RELATIONSHIP BETWEEN LOCAL COMMUNITY ACTIVITIES AND ACTIVITIES FOR DISASTER REDUCTION IN A FLOOD-PRONE AREA
}

\author{
山田 忠 1 ・柄谷友香 $2 \cdot$ 松本康夫 ${ }^{3}$
}

Tadashi YAMADA, Yuka KARATANI, Yasuo MATSUMOTO

\author{
1学生会員＼cjkstart岐阜大学大学院連合農学研究科（†501-1193 岐阜県岐阜市柳戸1-1） \\ 2正会員 博士（工） 名城大学大学院都市情報学研究科（†509-0261 岐阜県可児市虹ヶ丘4-3-3） \\ 3 非会員 農博＼cjkstart岐阜大学大学院連合農学研究科（干501-1193 岐阜県岐阜市柳戸1-1）
}

In this study, we examined the factor that community activity gave flood response and flood measure by questionnaire survey for Arasaki area. Firstly, we analyzed the influence that factor to give community activity and community activity gave flood response and flood measure by chi square test. Secondly, we perform the type of the respondent by quantification method 3 and cluster analysis, and analyzed a factor to give flood response and flood measure. As results, firstly, gender or age, the residence affected community activity. Secondly, the person that community activity was active participated in activities for flood disaster reduction and tended to expect flood measures in neighborhood inhabitants.

Key Words : local community activities, activities for disaster reduction, flood reduction measures

\section{1. はじめに}

近年，各地で予測困難な集中豪雨が発生しており，行 政による被害把握や避難情報の発令など迅速な水害対応 が喫緊の課題となっている．例えば，2009年8月兵庫県 佐用町で発生した豪雨では，最大時間雨量 $89 \mathrm{~mm} ，$ 最大 24時間雨量 $326.5 \mathrm{~mm}$ と佐用観測所史上最大を記録した. 発災当日8月9日19時頃から21時までの約2時間の間に佐 用観測地点での水位は $2 \mathrm{~m}$ も上昇し，一気に汇濫危険水 位に達した.この間，庁舎が浸水する中，町内に広く点 在する各地区の被害把握に追われ, 結果として避難勧告 が発令されたのは人的被害や家屋被害の後となった1).

こうした状況はこの件に限らず，各地の豪雨検証におい て重要課題として挙げられている22.

行政の水害対応の見直しが進められる一方で，地域コ ミュニティによる防災活動が一層重要視されている. し かしながら，わが国の地域防災活動をみてみると，例え ば消防団は，阪神・淡路大震災時の1995年に 98.3 万人で あったのに対し，2009年には 88.5 万人と約 $10 \%$ 減少し ている3)。 また，自主防災組織は，同震災以降増加し， 2009年には1,658市区町村で13万9,316まで増加し, 全世 帯に占める自主防災組織の活動カバー率は73.5\%に達し た.しかしながら，地域コミュニティの希薄化や高齢化 により，日頃の活発な防災活動や災害対応時の実効性に
は課題が残っている4).

既往の研究では，地域コミュニティの特性や活動が防 災活動に与える影響の検討がいくつか進められている.

例えば，藤田ら ${ }^{5}$ や岡西ら ${ }^{6}$ は，秋田市や横浜市を対象 に平時の地域コミュニティ活動と自主防災活動との関係 を調査し，活発なコミュニティ活動を行う組織では自主 防災組織も活発な傾向にあることや，自主防災活動を行 う上で地域リーダーの存在が大きいことを示唆している. 同様に，浅田ら ${ }^{7)}$, 千種ら ${ }^{8)}$, 松本ら ${ }^{9)}$ は，祭りや防災教 育など地域の大人から子どもまで交流できる活動の場が, 地域コミュニティに対する意識を向上させ，結果として 平時の防災活動の継続につながることを明らかにしてい る。また，崔ら ${ }^{10)}$ は，住環境が防災活動に与える影響を 調査し, 一戸建て中心の持ち家率が高く, 居住年数の長 い人ほど，コミュニティ活動が活発であり，かつ防災活 動も活発になる傾向を示唆している. さらに，春山ら ${ }^{11)}$ は，2004年の福井水害を対象として，被災前後の防災活 動の関係をヒアリング調査によって検討し, 被災前のコ ミュニティ活動が被災後のそれに影響することを明らか にしている，例えば，被災前のコミュニティ活動が活発 でない新興住宅地では，被災後の防災活動も低調にとど まるなど，住宅地特性別の傾向を整理している.

以上のように，既往研究では，コミュニティ活動が平 時の防災活動に与える影響に着目しており，実際の水害 発生時の対応に与える影響を検討したものはない. また， 
それらのコミュニティ活動が今後の水害対策への意向や 方向性に与える影響を分析したものもみられない.

前者に対しては，活発なコミュニティ活動が平時の防 災活動をも活性化させるという重要な視点であるが，昨 今豪雨が多発する中で，それらの活動がさらに水害発生 時やその後の復旧・復興活動に活かされることが急務と いえる．また，後者に対しては，現状把握にとどまらず， 今後の水害対策について，治水施設整備など行政への依 存傾向がみられる中，その限界も見据え，地域コミュニ ティによる共助や自助との役割分担を議論し，実効性を 高めることが地域防災力の向上につながるものといえる。

そこで本研究では，これらの課題解決に資するべく， 居住環境や水害認識等の住民属性とコミュニティ活動と の関係を検討した上で，コミュニティ活動への参加状況 が水害発生時から復旧・復興に至る対応や今後の水害対 策への役割分担意向に与える影響を検討寸る.

\section{2. 研究方法}

調查対象地域は，2002年に洗堰からの越流により床 上・床下浸水合わせて482棟もの被害を出した岐阜県大 垣市荒崎地区（図一1）とした.

まず，当該地区における各町コミュニティの特徴を表 -1に示した. なお，表一1は筆者ら ${ }^{12)}$ が2007年に実施し た各町自治会長に対する水害対応（2002年水害時）及び 平時のコミュニティ活動に関する詳細なヒアリング調査 に基づく.これによると，1960年～70年代以降，新規住 民の増加がみられる長松町と島町では, 自治会活動への 新規住民の参加が難しく, 水防体制への不参加や2002年 の水防活動時における役割分担などの協働が困難であり, 町としてまとまった活動ができないという。一方，旧住 民が多い十六町では, 今後の後継者問題はあるものの, 他の 2 町と比較して自治会活動が活発であり, 町として 独自の水防体制を設置し，水防活動を実施している.

本研究では，これらの結果を踏まえた上で，次のよう

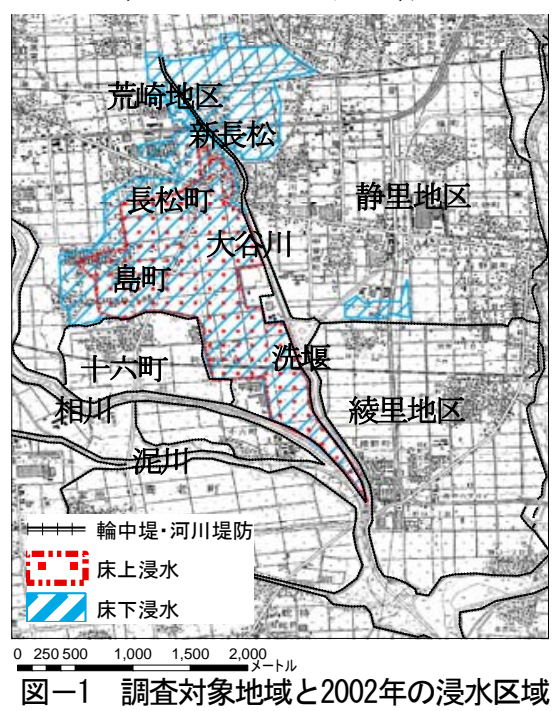

表－1 荒崎地区3町のコミュニティ特徵 (筆者 $^{12}$ を加筆修正)

\begin{tabular}{|c|c|c|c|}
\hline 町名 & 長松町 & 島町 & 十六町 \\
\hline $\begin{array}{c}\text { 人口 } \\
\text { (2005年 } \\
/ 1965 \text { 年) }\end{array}$ & $\begin{array}{l}\text { 1960年代より } \\
\text { 増加(3.46) }\end{array}$ & $\begin{array}{l}\text { 1970年代より増 } \\
\text { 加 (11.25) }\end{array}$ & $\begin{array}{l}\text { 1960年以降横 } \\
\text { ばい (1.04) }\end{array}$ \\
\hline 世帯数 & $\begin{array}{l}\text { 1960年代より } \\
\text { 増加 }\end{array}$ & 1970年代より増加 & 1960年以降微増 \\
\hline 町内問題 & 新規住民問題 & 新旧住民問題 & 過疎問題 \\
\hline $\begin{array}{l}\text { 水防体制 } \\
\text { での問題 }\end{array}$ & $\begin{array}{c}\text { 集合住宅の住 } \\
\text { 民が不参加 }\end{array}$ & $\begin{array}{c}\text { まとまった水防 } \\
\text { 活動が不可 }\end{array}$ & 後継者の問題 \\
\hline
\end{tabular}

な仮説を構築し，アンケート調査や数量化理論を用いて 検証することを目的とする.

「平時のコミュニティ活動が活発な人ほど，水害対応 時においても行政に頼らず，地域活動を通じて対応する 傾向にある．また，今後の水害対策についても，同様に， 行政に依存し過ぎず，個人や世帯，地域で取り組む傾向 にある.」

まず，個人属性や地域の違いによるコミュニティ活動 の差異について検討する. 次に, 平時のコミュニティ活 動が，水害時の情報取得や水防活動への参加など水害対 応に与える影響について分析する. さらに，平時のコ ミュニティ活動が，水害常習地域において今後取り組む べき水害対策への意向（重要視）に与える影響を分析す る. なお，これらの水害対応及び水害対策については 「誰が担ったのか・担うべきか」の役割分担や考え方が 明確になるように設問上の工夫をした。 このことにより， 水害常習地域における水害対応や水害対策に対寸る役割 分担が明確になるだけでなく，冒頭に述べたように，今 後一層重要となる共助や自助を促すための方策を, 平時 のコミュニティ活動のあり方を含めて検討することがで きる. また, 各世帯でのコミュニティ活動や水害対応, 対策の実態を把握すべく, 回答者を世帯主とした.

分析方法は，まず，クロス集計と $\chi^{2}$ 検定により，コ ミュニティ活動が水害対応や水害対策に与える影響を検 討した. また, 数量化而類とクラスター分析を用いて, 回答者の類型化を行い，水害対応や水害対策に与えてい る要因を検討した.

表一2 アンケート調査概要

\begin{tabular}{|c|c|}
\hline \multicolumn{2}{|r|}{ アンケート調査概要 } \\
\hline 実施日 & 2009年9月14日及び16日 \\
\hline 対 象 & 大垣市荒崎地区4町 \\
\hline 配布数 & 1996票 \\
\hline 回収率 & $39.1 \%$ \\
\hline 有効回答 & 781票 \\
\hline & アンケート調査の主な質問と項目 \\
\hline (1)個人属性 & $\begin{array}{l}\text { 性別・年齢・居住年数・居住理由・浸水深・地域の水害認 } \\
\text { 識・超過洪水認識・土地の危険度訫識 }\end{array}$ \\
\hline $\begin{array}{l}\text { (2) コミュニ } \\
\text { ティ活動 }\end{array}$ & $\begin{array}{l}\text { 日常の自治会活動への参加状況・自主防災への参加状況・ } \\
\text { 消方団への入団状況 }\end{array}$ \\
\hline $\begin{array}{l}\text { (32002年の水 } \\
\text { 害対応 }\end{array}$ & $\begin{array}{l}\text { 気象や河川の出水などの情報取得態度, 土囊積みや堤防監視 } \\
\text { などの水防活動への参加柷, 地域の掃除や被災した家屋の } \\
\text { 手伝いな゙の復旧・復興活動への参吠犬況 } \\
\end{array}$ \\
\hline $\begin{array}{l}\text { (4)今後の水害 } \\
\text { 対策への意向 }\end{array}$ & 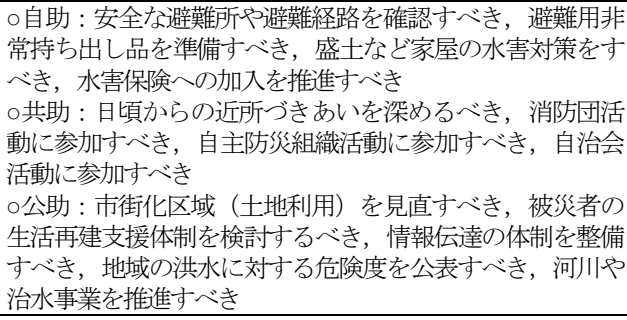 \\
\hline
\end{tabular}




\section{3. アンケート調査の概要}

\section{(1) アンケート調査内容}

質問紙は先述の仮説をもとに設計し，アンケート調査 の概要は表－2に示した．表一2のように，質問紙は，(1)

個人属性，(2)コミュニティ活動，(322002年の水害対応， (4)今後の水害対策への意向の4項目で構成されている.

各項目の回答方法は, (2)コミュニティ活動は自治会や 自主防災組織への参加活動状況を4，5段階で尋ね，(3) 2002年の水害対応は，個人や世帯（自助），地域コミュ ニティ (共助)，行政（公助）のいずれによって対応し た（もしくは，任せた）のか役割分担が明確になるよう に尋㸚た. 最後に, (4)今後の水害対策への意向について は，自助，共助，公助のそれぞれに関する質問を設定し，

「そう思う」から「そう思わない」までの5件法とした。

アンケート調査は, 2009年9月に荒崎地区4町1987世帯 を対象にポスティング配布し，郵送回収とした．その結 果, 有効回答数は781票（有効回答率 $39.1 \%$ ）であった.

そのうち, 先の調査でコミュニティ活動及び水害対応 の実態を把握した大谷川右岸3町の544票を用いて分析を 実施した.

\section{（2）回答者属性の概要}

回答者属性の概要を表一3に示した。これによると, 回答者は，男性が女性よりも多く，年齢は50代から60代 が多い. 居住年数は 20 年から 39 年が $42.8 \%$ を占め, 居住 理由では「先祖代々の土地」が $26.8 \%$ で多いものの,

「地価が手頃」が22.6\%と多いことも特徵的である.

\section{（3）コミュニティ活動の地域比較}

ここでは，本研究において重要な指標となるコミュニ ティ活動の地域比較を行った上で, 以後の分析に用いる ための点数化について説明する.

図一2から4には，各町における自治会への参加・活動

表－3 アンケート調査の主な結果

\begin{tabular}{|c|c|}
\hline 性 別(n=544) & 男性(67.8\%), 女性(32.2\%) \\
\hline 年 齢(n=544) & $\begin{array}{l}20 \text { 代 }(0.9 \%), 30 \text { 代 }(5.7 \%), 40 \text { 代 }(13.8 \%), 50 \text { 代 } \\
(27.4 \%), 60 \text { 代(32.5\%)，70代(16.9\%)，80代以上 } \\
(2.8 \%)\end{array}$ \\
\hline $\begin{array}{l}\text { 居 住 年 数 } \\
(\mathrm{n}=530)\end{array}$ & $\begin{array}{l}9 \text { 年以下 }(11.0 \%), \quad 10 \sim 19 \text { 年 }(16.7 \%), \quad 20 \sim 29 \text { 年 } \\
(21.1 \%), 30 \sim 39 \text { 年 }(21.7 \%), 40 \sim 49 \text { 年 }(16.0 \%), 50 \\
\sim 59 \text { 年(6.4\%), } 60 \text { 年以上(7\%) }\end{array}$ \\
\hline $\begin{array}{l}\text { 居 住 理 由 } \\
(\mathrm{n}=660)\end{array}$ & $\begin{array}{l}\text { 先祖代々の土地 }(26.8 \%), \text { 実家に近い }(10.3 \%), \text { 交 } \\
\text { 通の利便性がよい }(7.0 \%), \text { 地価が手比 }(22.6 \%) \text {, 自 } \\
\text { 然が多く, 快適( }(8.9 \%) \text {, 災害が少ない }(2.4 \%), \text { 犯 } \\
\text { 罪が少ない }(3.6 \%), \text { その他 }(18.3 \%)\end{array}$ \\
\hline 浸水深(n=525) & $\begin{array}{l}\text { 浸水経験なし }(39.6 \%), \text { 床下浸水経験 }(25.3 \%) \text {, 床 } \\
\text { 上浸水経験 }(35.0 \%)\end{array}$ \\
\hline $\begin{array}{l}\text { 水 害 認 識 } \\
(\mathrm{n}=533)\end{array}$ & $\begin{array}{l}\text { 水害は人災である }(68.1 \%), \text { 水害は仕方がない } \\
(31.9 \%)\end{array}$ \\
\hline $\begin{array}{l}\text { 超過洪水認識 } \\
(\mathrm{n}=533)\end{array}$ & $\begin{array}{l}\text { 超過洪水は防げる(76.4\%), 超過洪水は防げない } \\
(23.6 \%)\end{array}$ \\
\hline $\begin{array}{l}\text { 土地の危険度認 } \\
\text { 識(n=537) }\end{array}$ & $\begin{array}{l}\text { 安全な土地である }(10.1 \%), \text { 危険な土地である } \\
(89.9 \%)\end{array}$ \\
\hline
\end{tabular}

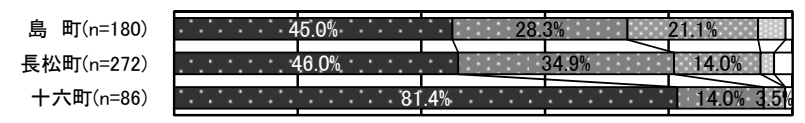

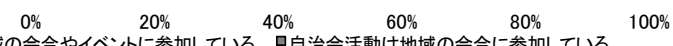
ロ自治会活動は地域の会合動を行っている 口自治会に入会しいない 図-2 各町の自治会への参加状況

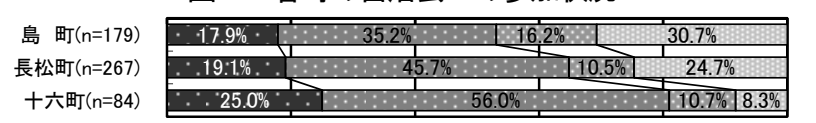

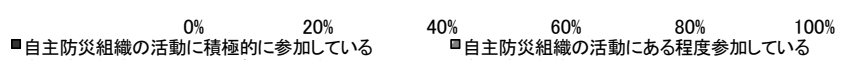

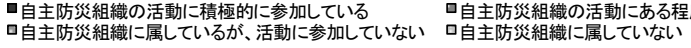
図-3 各町の自主防災活動への参加状況

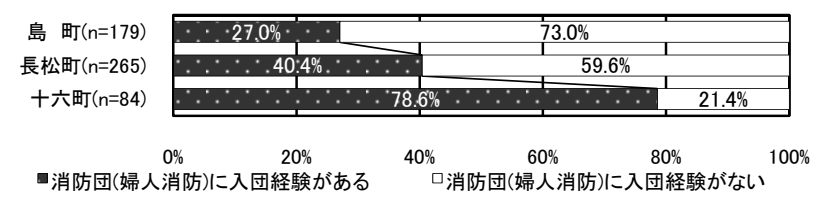
図-4 各町の消防団への入団経験

状況，自主防災組織への参加・活動状況，消防団への入 団状況を示した. まず，自治会への参加状況（図一2） は，各町ともに会合まで参加している割合が70\%を超え ている．特に，十六町では，イベントまで積極的に参加 している人のみで $80 \%$ を超えている. 次に，自主防災組 織への参加状況（図一3）は，積極的及びある程度活動 している人を含めると, 十六町は $81.0 \%$ と非常に高く, 次いで, 長松町 (64.8\%), 島町 $(53.1 \%)$ の順に低く なる．さらに，消防団への入団状況（図一4）は，十六 町では78.6\%が入団経験をしており，一方で，島町では 27.0\%にとどまっている.

以上より，コミュニティ活動への参加・活動状況は各 町によって異なり, また, 日頃の自治会活動の会合やイ ベントに積極的に参加している人ほど, 自主防災組織で の参加状況が活発であり, かつ, 消防団への入団経験も 高まる傾向がみられた.

4章以降では，これら3つのコミュニティ活動状況を点 数化した「コミュニティ活動度」を用いて分析を進める. なお，点数化に際しては，組織に属するだけでなく， 活動に参加している点を重視し，「自治会の会合やイベ ント（会合のみを含む）に参加している」，「自主防災 組織に参加している（ある程度も含む）」，「消防団一 の入団経験がある」をそれぞれ 1 点とし，それ以外を 0 点 とした. これら項目をそれぞれ得点化し，その合計点 を「コミュニティ活動度」とし，以降の分析では0から3 点の四段階で表寸ものとした.

\section{4. コミュニティ活動が防災活動に与える影響}

\section{（1）個人属性がコミュニティ活動に与える要因分析}

個人属性8項目とコミュニティ活動度について $\chi^{2}$ 検定 を実施した結果を表一4に示した（以降，**1\%有意， *5\%有意と表す）。表一4より，コミュニティ活動には, 性別, 年齢, 居住年数, 居住理由が影響している. 一方 
表－4 個人属性とコミュニティ活動との $\chi^{2}$ 検定結果

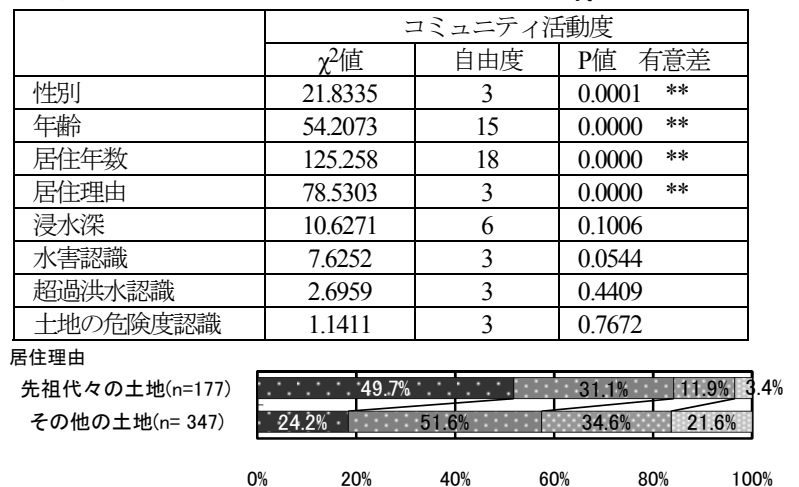

図一5 居住理由とコミュニティ活動

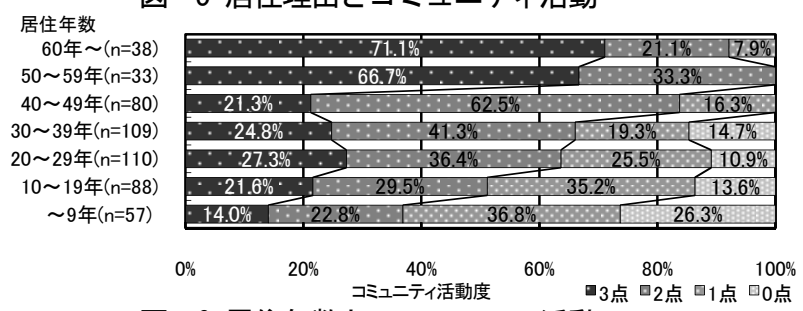

図一6 居住年数とコミュニティ活動

で，浸水深や水害受容度（天災か人災か），超過洪水認 識（超過洪水を防げるか娝か），土地の危険度認識（土 地は危険か安全か) は影響を与えていなかった。

次に，有意な関連性がみられた居住理由及び居住年数 とコミュニティ活動との関係を図ー5及び図ー6に示した.

これらによれば，先祖代々の土地に住み，また，居住 年数が長くなるほど，コミュニティ活動が活発になるこ とがわかった。

\section{（2）コミュニティ活動が水害対応に与える要因分析}

本節では，コミュニティ活動が気象や河川情報などの 情報取得, 堤防監視や土囊積みなどの水防活動，地域の 清掃や被災した家屋の手伝いなどの復旧・復興活動の3 つの水害対応フェーズに与える要因を検討寸る.

まず，コミュニティ活動度と水害対応について $\chi^{2}$ 検定 を実施した結果を表一5に示した。これによれば，コ ミュニティ活動と水防活動及びその後の復旧・復興活動 への参加状況に関連性がみられた.

次に，コミュニティ活動と有意な関連性がみられた水 防活動 の参加状況と復旧・復興活動の参加状況をそれ ぞれ図ー7及び図ー8に示した。 これらによれば，平時の コミュニティ活動が活発な人の方が，水害時の水防活動 やその後の復旧・復興活動に対して，個人や世帯（自助） または地域（共助）で取り組む割合が高くなる，一方で， 活発でない人の方が行政に依存する割合が高くなる傾向 にある。

以上より，平時のコミュニティ活動は，水害対応の中 でも水防活動や復旧・復興活動への参加状況に影響を与 えていた. また，コミュニティ活動が活発な人の方が, 行政の夕に頼るのでなく, 個人や世帯, 地域により水害 対応を行う傾向が示唆された.
表－5 コミュニティ活動と水害対応との $\chi^{2}$ 検定結果

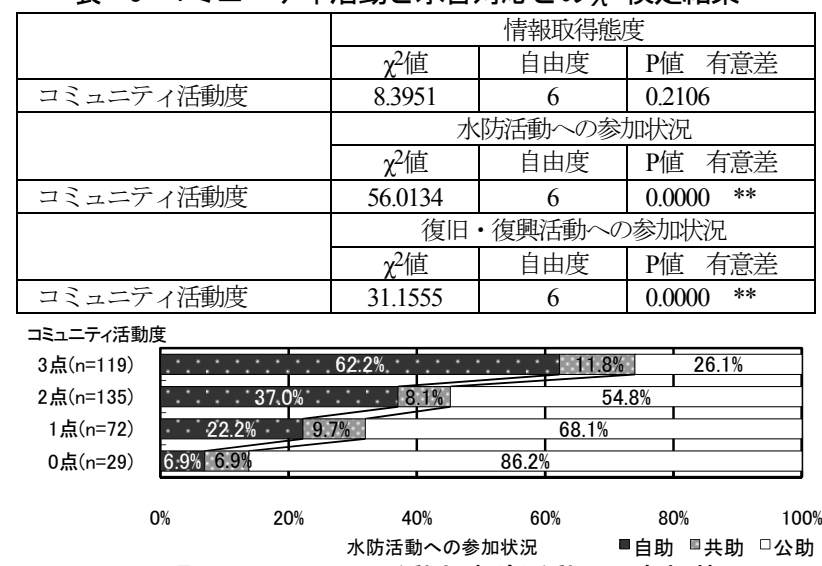

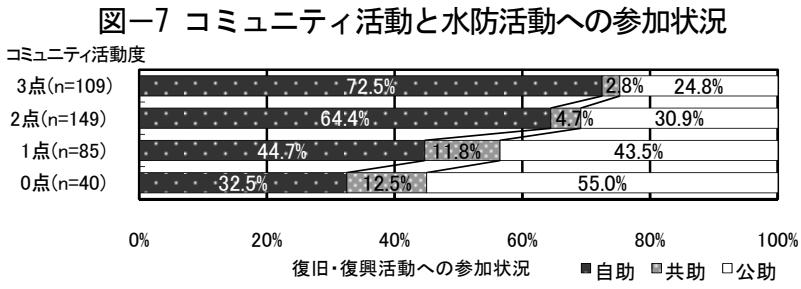

図ー8 コミュニティ活動と復旧・復興活動への参加状況

\section{（3）コミュニティ活動が今後の水害対策に与える要因分析}

本節では，コミュニティ活動が水害常習地域におけ る今後の水害対策への意向に与える要因を検討する.

まず，コミュニティ活動度と今後の水害対策への意向 について $\chi^{2}$ 検定を実施した結果を表一6に示した。なお, 自助, 共助, 公助に相当する設問の詳細は表一2を参照 されたい. また，「そう思う」から「そう思わない」の 5件法を5点から1点で点数化を行い，各項目を平均点で 算出した. これによれば，コミュニティ活動と共助及び 公助に関わる項目との関連性がみられた.

次に，コミュニティ活動と有意な関連性がみられた共 助及び公助との関係を図一9及び図ー10に示した.

表一6 コミュニティ活動と水害対策との $\chi^{2}$ 検定結果

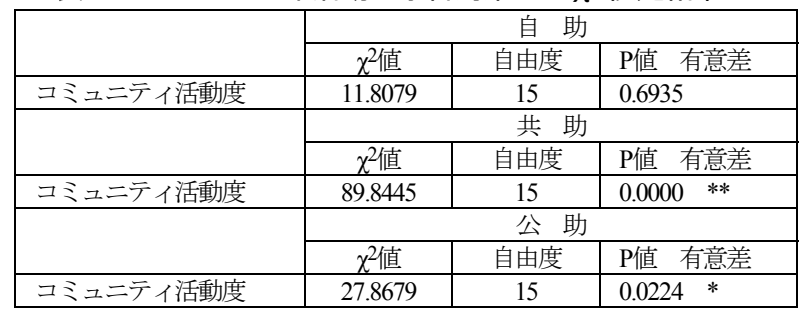

\section{コミュニティ活動度}

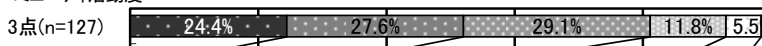

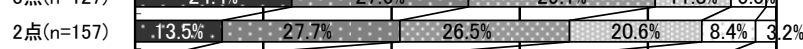

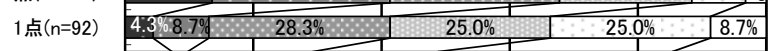

\begin{tabular}{ll|l|l|l|l|l|l|}
\hline & 点 $(n=41)$ \\
\hline
\end{tabular}

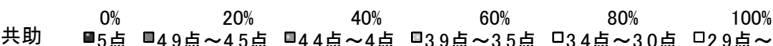
図一9コミュニティ活動と共助による水害対策

コミュニテイ活動度

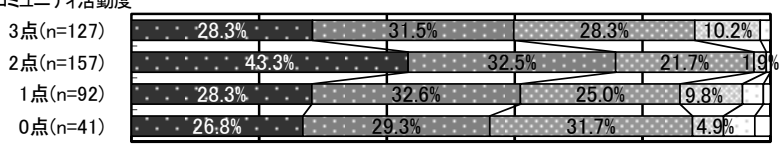

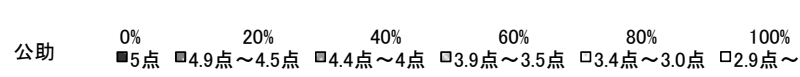
図ー10 コミュニティ活動と公助による水害対策 
表ー7 アイテムとカテゴリ一概要

\begin{tabular}{|c|c|c|}
\hline アイテム & カテゴリー & 反忘数 \\
\hline \multirow{2}{*}{ 自治会活動 } & 自治会活動が非活発 & 95 \\
\hline & 自治会活動が活発 & 395 \\
\hline \multirow{2}{*}{ 自主防災組織での活動 } & 自主防災活動が非活発 & 174 \\
\hline & 自主防災活動が活発 & 316 \\
\hline \multirow{2}{*}{ 消防団一の入団状況 } & 入団経験なし & 282 \\
\hline & 入団経験あり & 208 \\
\hline \multirow{2}{*}{ 水害認識 } & 水害は人災である & 334 \\
\hline & 水害は仕方がない & 156 \\
\hline \multirow{2}{*}{ 超過洪水認識 } & 超過洪水は防げる & 371 \\
\hline & 超過洪水は防げない & 119 \\
\hline \multirow{2}{*}{ 土地の危険度認識 } & 安全な土地 & 48 \\
\hline & 危険な土地 & 442 \\
\hline \multirow{2}{*}{ 性別 } & 男性 & 332 \\
\hline & 女性 & 158 \\
\hline \multirow{3}{*}{ 年齢 } & 40代以下 & 105 \\
\hline & 50代〜60代 & 300 \\
\hline & 70代以上 & 85 \\
\hline \multirow{3}{*}{ 居住年数 } & 居住年数19年以下 & 139 \\
\hline & 居住年数 20 年 49年以下 & 283 \\
\hline & 居住年数50年以上 & 68 \\
\hline \multirow{2}{*}{ 居住理由 } & 先祖代々の土地 & 166 \\
\hline & その他の土地 & 324 \\
\hline \multirow{3}{*}{ 浸水深(浸水経験) } & 浸水経験無 & 194 \\
\hline & 床下浸水経験 & 124 \\
\hline & 床上浸水経験 & 172 \\
\hline
\end{tabular}

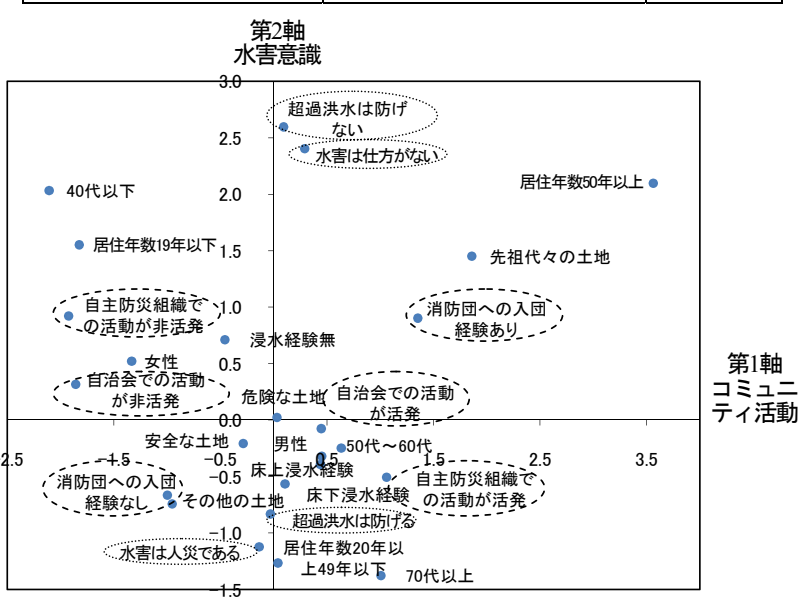

図ー11 カテゴリープロット

これらによれば，まず，コミュニティ活動が活発な人 の方が自主防災組織への参加など共助に対する取り組み を重視する傾向がみられた（図一9）。一方，コミュニ ティ活動と公助による水害対策への意向については，顕 著な傾向がみらなかった（図一10）。このことは，「コ ミュニティ活動が活発な人ほど “行政に依存し過ぎず” 共助で取り組む傾向がみられる」という仮説を一部検証 し得ないものといえる。したがって，次章では，公助に よる水害対策への意向に対して，コミュニティ活動以外 の要因の抽出及びその影響について検討を進める.

\section{5. 水害対応及び対策への意向に与える要因の抽出}

本章では，数量化III類とクラスター分析による回答者 の類型化を行い，水害対応や対策意向へのコミュニティ 活動以外の影響要因の抽出とその影響について分析する. まず，表ー7のようにアイテムとカテゴリーを分類し
表-8 数量化而類の結果

\begin{tabular}{|c|c|c|c|c|c|c|}
\hline カテゴリー & 1軸 & 2軸 & 3 軸 & 4軸 & 5軸 & 6軸 \\
\hline 自治会活動が非活発 & -1.858 & 0.316 & 1.121 & 2.793 & -1.531 & 3.048 \\
\hline 自治会活動が活発 & 0.447 & -0.076 & -0.270 & -0.672 & 0.368 & -0.733 \\
\hline 自主防災活動が非活発 & -1.924 & 0.921 & 0.573 & 0.674 & -0.471 & 1.045 \\
\hline 自主防災活動が活発 & 1.060 & -0.507 & -0.316 & -0.371 & 0.259 & -0.575 \\
\hline 消防団への入団なし & -0.998 & -0.665 & -0.407 & -0.309 & -0.693 & 0.008 \\
\hline 消防団への入団あり & 1.353 & 0.902 & 0.552 & 0.419 & 0.939 & -0.011 \\
\hline 水害は人災である & -0.136 & -1.123 & 0.865 & 0.187 & 0.037 & -0.234 \\
\hline 水害は仕方がない & 0.291 & 2.404 & -1.851 & -0.401 & -0.078 & 0.502 \\
\hline 超過洪水は防げる & -0.030 & -0.833 & 0.559 & 0.356 & 0.314 & -0.621 \\
\hline 超過洪水は防げない & 0.094 & 2.597 & -1.741 & -1.111 & -0.979 & 1.938 \\
\hline 安全な土地 & -0.285 & -0.208 & -3.453 & 5.284 & 3.176 & -3.382 \\
\hline 危険な土地 & 0.031 & 0.023 & 0.375 & -0.574 & -0.345 & 0.367 \\
\hline 男性 & 0.634 & -0.248 & 0.276 & 0.374 & 0.147 & 0.109 \\
\hline 女性 & -1.333 & 0.521 & -0.579 & -0.785 & -0.308 & -0.229 \\
\hline 40代以下 & -2.107 & 2.032 & 1.744 & -0.966 & 2.174 & -1.494 \\
\hline 50代～60代 & 0.452 & -0.321 & -0.725 & -0.164 & -1.703 & -0.706 \\
\hline 70代以上 & 1.007 & -1.378 & 0.404 & 1.774 & 3.325 & 4.337 \\
\hline 居住年数19年以下 & -1.824 & 1.552 & 1.765 & -0.084 & 0.968 & -1.432 \\
\hline 居住年数20年～49年以下 & 0.040 & -1.266 & -1.267 & -0.409 & -0.380 & 0.579 \\
\hline 居住年数50年以上 & 3.562 & 2.098 & 1.664 & 1.872 & -0.398 & 0.515 \\
\hline 先祖代々の土地 & 1.860 & 1.452 & 0.833 & -0.021 & -0.343 & -0.243 \\
\hline その他の土地 & -0.953 & -0.744 & -0.427 & 0.011 & 0.176 & 0.125 \\
\hline 浸水経験無 & -0.457 & 0.711 & -1.752 & 1.699 & 0.166 & -0.586 \\
\hline 床下浸水経験 & 0.107 & -0.566 & -0.121 & -3.094 & 2.540 & 1.415 \\
\hline 床上浸水経験 & 0.439 & -0.394 & 2.063 & 0.314 & -2.019 & -0.358 \\
\hline 固有值 & 0.219 & 0.148 & 0.133 & 0.105 & 0.096 & 0.094 \\
\hline 累積寄与率 & 0.172 & 0.288 & 0.393 & 0.475 & 0.550 & 0.624 \\
\hline 相関係数 & 0.468 & 0.385 & 0.364 & 0.324 & 0.310 & 0.307 \\
\hline
\end{tabular}

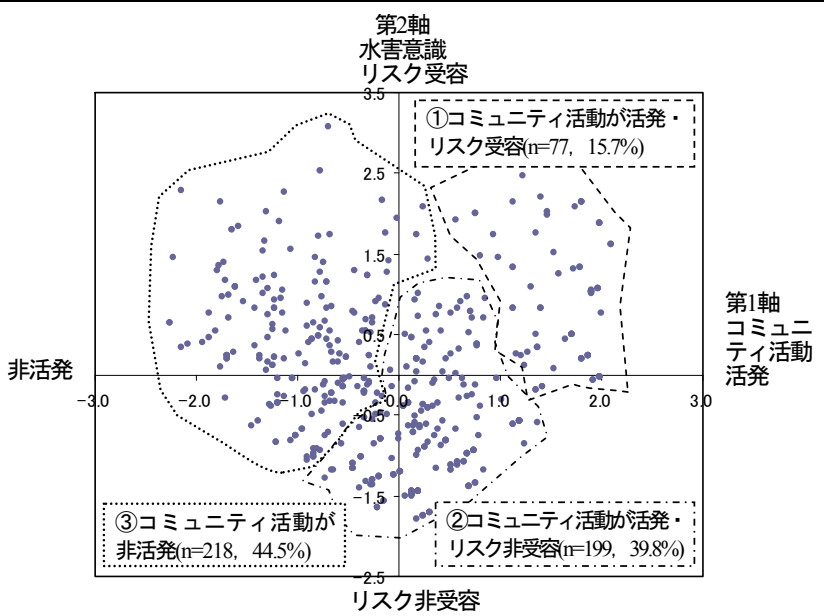

図-12 サンプルプロットと類型化

た上で，累積寄与率が60\%になるように数量化III類を実 施した結果を表一8に示した。これによれば，第1軸は，

「自治会活動が活発」や「自主防災活動が活発」が正側, 一方で非活発が負側に寄与していることから，「コミュ 二ティ活動軸」と解釈した。第2軸は，「水害は仕方が ない」，「超過洪水は防げない」が正側，「水害は人災 である」，「超過洪水は防げる」が負側に寄与しており， 「水害意識軸」と解釈した。

次に，数量化で得られたカテゴリースコアを図ー11, サンプルスコアについてクラスター分析（ウォード法） を実施し，プロットした結果を図ー12に示した. 図ー12 によれば，(1)コミュニテイ活動が活発であり，水害リス クを受容している，(2)コミュニティ活動が活発であり， 水害リスクを受容していない，(3)コミュニティ活動が非 活発の3グループに大別された.

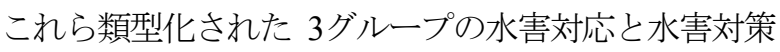




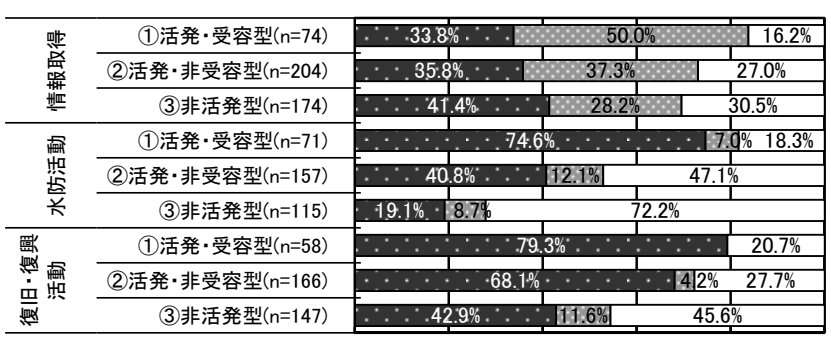

$\begin{array}{lllll}0 & 0\end{array} \quad 20 \% \quad 40 \% \quad 60 \% \quad 80 \% \quad 100 \%$

図ー13 3グループの水害対応

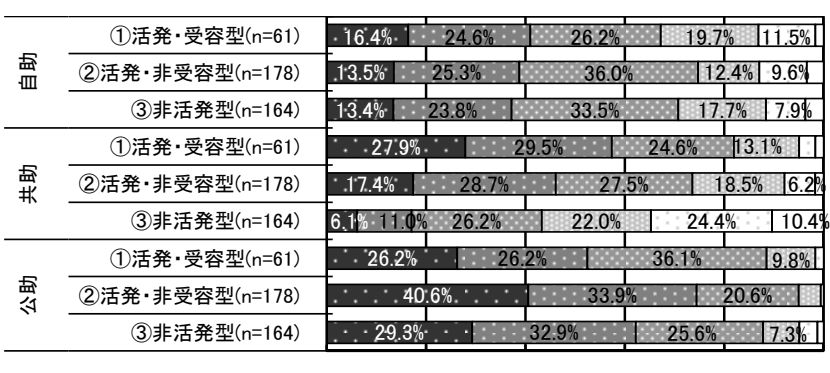

$0 \% \quad 20 \% \quad 40 \% \quad 60 \% \quad 80 \% \quad 100 \%$

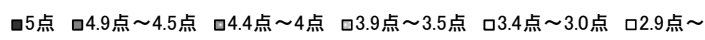

図ー14 3グループの今後の水害対策への意向

のあり方の特徴を示した上で，水害対応や水害対策に与 えている要因を比較検討する.

まず，3グループの水害対応を図ー13に示した。この 図によれば，コミュニテイ活動が活発であるグループ(1) と(2)の方が非活発な(3)に比べて，3つの対応全てに，行 政に依存することなく自助と共助で対応する傾向にある

また，中でも，水害リスクを受容しているグループ(1) の方が(2)に比べて，水防活動に参加寸る傾向がみられる。

次に，3グループの今後の水害対策への意向を図-14 に示した.まず，共助への回答に着目すれば，コミュニ ティ活動が活発であるグループ(1)と(2)の方が(3)より重要 視している傾向がみられる. また，前章でコミュニティ 活動と関連性がみられた公助は，コミュニティ活動が活 発な人のうち，水害リスクを受容していないグループ(2) の方が期待する傾向にある. なお，自助については，グ ループによる差異はみられなかった。

以上より，水害対応や今後の水害対策に影響を与える 要因を抽出した結果，コミュニティ活動とともに水害リ スク受容が影響を与えていた。平時のコミュニティ活動 が活発な人ほど，水害対応においても，行政に依存する ことなく，個人・世帯，地域住民の力で乗り切る傾向が 示唆された。 また，水害リスク受容をしていない人の方 が公助による水害対策を重視する傾向が示唆された。

\section{6. おわりに}

本研究では，コミュニティ活動への参加状況が水害発 生時から復旧・復興に至る対応や今後の水害対策への役 割分担意向に与える影響を検討した．得られた結果は以 下の通りである。
（1）コミュニティ活動には，性別や年齢，居住年数や 居住理由が影響を与えており，先祖代々の土地に居住し， 居住年数が長いほど，コミュニティ活動へ活発に参加す る傾向が示唆された。

（2）気象や河川出水などの情報取得，土囊積みなどの 水防活動，地域の清掃や被災した家屋の手伝いなどの復 旧・復興活動の3つの水害対応のうち, コミュニティ活 動が活発的な人は，3つの水害対応全てに個人や世帯 （自助）及び地域（共助）で取り組む傾向が示唆された。 （3）今後の水害対策への意向（重要視）については, コミュニティ活動が活発な人ほど，共助による対策を重 視する傾向が示唆された.

（4）水害対応や今後の水害対策への意向には，コミュ 二ティ活動以外に水害リスク受容も影響しており，水害 リスクを受容していない人ほど公助による水害対策を重 視する傾向が示唆された.

以上より，地域コミュニティによる主体的な水害対応 や対策に向けて，防災訓練など防災に特化した活動はも とより，その初期段階である自治会活動など平時のコ ミュニティ活動への参加を促す取り組みが希求される.

最後に，被災経験や水害知識など水害リスク受容に与 える要因の詳細を分析することや，水害常習地域でない 他地域との比較検討が今後の課題である.

謝辞：本研究は，日本学術振興会科学研究費若手研究 (A)「災害対応ナレッジデータベース（KDDM）の構 築と自治体防災研修への実践的活用」（研究代表者 : 柄 谷友香) による成果の一部である.

\section{参考文献}

1) 佐用町 : 佐用町台風第9号災害検証報告書, 2010 .

2) 岐阜県 : 7.15 豪雨災害検証報告書, 2010.

3) 内閣府 : 防災白書 平成22年度版, 2010.

4) 消防庁: 消防白書一消防と医療の連携の推進 消防と医療の連携 による救急搬送の円滑化 平成21年版一，日経印刷，2009.

5) 藤田勝・清水浩市郎・木村一裕・佐藤陽介 : 活発な自主防災活 動と日常的な地域活動の関連性に関寸る研究一秋田市の状況か ら一，都市計画論文集 Vol.38-3，pp.19-24， 2003.

6) 岡西靖・佐土原聡 : 地域防災力向上のための自治会町内会にお ける地域コミュニティと災害対策に関する調査研究, 日本建築 学会計画系論文集 No.609, pp.77-84, 2006.

7) 浅田麻記子・落合知帆・小林正美 : 岐阜県白川村における地域 防災活動の実態に関する研究一火の番回りと防火水利の維持管 理一, 都市計画報告集 No.8-1, pp.88-91， 2009.

8) 千種佑佳子・落合知帆・小林正美 : 災害常習地における地域住 民の自主防災一愛媛県西条市禎瑞地区を事例として一, 都市計 画報告集 No.8-4, pp.189-192， 2010.

9) 松本美紀・矢田部龍一: 実被災者地域住民における地域防災活動 継続意図の規定因, 自然災害科学 Vol.27-3, pp.319-330, 2008.

10)崔榮和・樋口大介・北後明彦・室崎益輝 : 住環境が防災コミュ ニティ活動に及ぼす影響に関する研究一神戸市を事例として一, 地域安全学会論文集 No.6, pp.283-290, 2004.

11)春山成子・水野智 : 2004 年福井水害にみる災害特性と地域防災 力に関寸る考察，自然災害科学 Vol.26-3, pp.303-322, 2007.

12)山田忠・柄谷友香 : 2002 年荒崎水害にみる土地利用変化と水防体制と の関連性に関寸る調査研究，水工学論文集 No.53，pp.577-582，2009.

(2010. 9. 30受付) 